\title{
Cultural Policy Directions: Historical Narratives and Suburban Development in Campbelltown
}

Penny Stannard

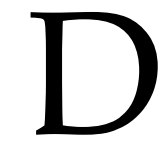

uring 2010 a debate was played out in a Campbelltown

newspaper concerning the cultural policy direction pursued by

Campbelltown City Council through its award-winning arts

centre. Claims were made that the council's core instrument of cultural policy, the Campbelltown Arts Centre, which is located in outer suburban south-west Sydney, was more focussed on providing opportunities for artists from Sydney's inner city - the 'Sydney arts scene' - than its local arts community. ${ }^{1}$ Defenders of the Arts Centre proudly pointed to its recent achievement in gaining multi-art form status from the Australia Council, the national arts funding body. This signified that Campbelltown had attained a new level of prestige that valued and recognised it as part of the national contemporary cultural scene. At the same time, however, Campbelltown's Mayor confirmed that

Sydney Journal

Vol 4, No 1 (2013): 99-111

ISBN: 1835-0151

(c) UTSePress and the author 
the Arts Centre's core role 'should be the creative hub for the local arts community'.2

At the time, the debate was reported to have 'sparked a furore'. ${ }^{3}$ Central to the discussion was whether the Arts Centre should focus its efforts on supporting local cultural activity that would generate a sense of 'home grown' identity and place rather than bypassing the community and producing programs that would enable it to attain a level of cultural prominence in order confirm Campbelltown's identity as a place of national importance. It was not the first time that the intersections between local cultural activity, national recognition and the evolving identity of Campbelltown have arisen, and cultural policy studies can provide a lens through which to examine how these discussions have their roots in earlier times. This article examines the history of cultural policy direction in Campbelltown to uncover the foundations of the recent concerns with local cultural activity and agendas of national recognition. Attention is given to how these concepts have intersected and what this has meant for the cultural identity of Campbelltown as a modern, progressive, outer-suburban place.

\section{SUBURBiA AND CULTURAL POLICY}

In articulating the fundamental concerns of cultural policy, Australia's most eminent cultural economist, David Throsby, has observed that one of its key objectives is cultural identity, something that is constructed through the recognition and celebration of national, regional and local identities. ${ }^{4}$ The Campbelltown debate would suggest that the Council's cultural policy direction is forged upon how its Arts Centre functions as an instrument of policy to construct a cultural identity for Campbelltown that is founded upon achieving recognition and value at a national level for cultural activity that has its roots in its outer suburban locale.

Questions around the integrity of commitment towards supporting local cultural development are raised through the debate in claims that the Council's support for cultural activity prioritises inner-Sydney based artists at the expense of local suburban cultural producers. This marking of geo-cultural binaries within the debate provides an important point in exploring how suburban places are situated conceptually within the cultural policy discussion.

Cultural policy is an area of public policy that has gained recent attention due to the release in 2011 of the National Cultural Policy Discussion Paper, which outlined the development of the first national cultural policy since Paul Keating's 1994 Creative Nation. ${ }^{5}$ The Discussion Paper largely ignores the spatial dimensions of cultural policy, including 
the cities of Australia within which suburbia is the dominant urban form. ${ }^{6}$ Other recent cultural policy approaches also ignore or exclude suburban areas, most noticeably the creative cities thesis made famous by Richard Florida. ${ }^{7}$ Chris Gibson and Chris Brennan-Horley have observed that the creative cities approach has an inherent inner-city bias that determines spaces outside these zones, such as suburbia, as uncreative and therefore exclusive to the cultural policy discussion. ${ }^{8}$ In addressing this, Gibson, Brennan-Horley and the recent Creative Suburbia group have measured levels of creative activity in Australian suburbs to ascertain how it contributes to wider regional economies and to make a rationale for including suburban Australia within the cultural policy discussion. ${ }^{9}$ This work has been carried out through the creative industries lens and has made an important contribution towards understanding the extent of cultural activity in suburban Australia. Missing from the body of published work on this subject, however, are the historical dimensions of cultural activity and policy.

In addressing this research gap an opportunity emerges to examine the depth and extent of cultural activity in suburban Australia historically and, more critically, to determine how this has influenced more recent cultural policy discussions. A point of entry into this investigation is through the Campbelltown debate, which provides the basis on which to develop a case study.

The period under review extends from the mid 1950s to the early 1960s. At this time Campbelltown commenced its urban transition from post-colonial farms and villages to a late twentieth-century, outersuburban Sydney landscape. At the same time on a broader level there was a growing sense that Australia needed to develop its own cultural identity as an independent nation state. ${ }^{10}$ Campbelltown has had a long history of engagement with cultural policy direction, particularly the policy elements associated with notions of cultural identity and suburban development, and the points of intersection that occur between these elements and across the policy spectrum as it extends from local to national concerns. A prominent feature of this has been locally developed cultural activity that can be recognised and celebrated on a national stage.

The term 'cultural policy direction' is used here as a way of encompassing public support for cultural activity that extends from both the 'ad hoc' to that which is systematically directed through formalised policy models. ${ }^{11}$ While not suggesting that the arts alone constitute a definition of culture or is the sole concern of cultural policy, this follows both Deborah Stevenson and Deborah Mills' observations that cultural policy to a large extent becomes 'operationalised' through the arts and 
heritage spheres. ${ }^{12}$ Operating as a contemporary arts-producing venue in the outer south-west Sydney region, Campbelltown Arts Centre was opened in 2005. It promotes itself and has been credited as being at the cutting edge of contemporary arts in Australia.

\section{CUlture AND the Master Planned Estate}

Campbelltown Arts Centre (pictured on page 5) is part of the master planned estate of large lifestyle facilities that include an expansive entertainment, hotel, gaming and leisure facility, shopping mall, private hospital and the Central Park development, consisting of a created heart of wetlands, ornamental ponds, cascades and a golf course. This cluster of public and private facilities can be understood as providing services and amenities for what Gabrielle Gwyther has described as the region's suburban aspirational communities. ${ }^{13}$ The Arts Centre, with its cutting edge architectural design, contemporary art program, sculpture garden of modernist art and 'Zen' Japanese garden, forms the cultural centrepiece within the master plan. In this context, the Arts Centre as a materialisation of cultural policy direction, signifies that Campbelltown is a suburban place that is ambitiously progressive and aspirational. Its cultural identity speaks boldly of an Australian outer suburban modernity.

Running directly through Campbelltown Arts Centre is Fisher's Ghost Creek. The creek was once a natural waterway that was engineered into an underground concrete drainage system to run beneath a major arterial road that connects Campbelltown to Wollongong. Apart from its physical location, the creek and its namesake, Fisher's Ghost, have a lot more in common with Campbelltown Arts Centre than first meets the eye.

The legend of Fisher's Ghost, an established and celebrated cultural narrative, materialised as a policy instrument in the mid-1950s that was inextricably linked to Campbelltown's emergence as a modern suburban space. This provided the historical groundwork from which cultural policy direction later evolved into the Campbelltown Arts Centre.

\section{SUBURBANISATION BEGINS}

Campbelltown was established as an agricultural settlement in the early 1800 s and remained largely rural until the 1950s. ${ }^{14}$ This changed with the NSW Government's Cumberland Plan (1948) which had been developed to address the growing needs of Sydney's expanding population. Campbelltown, located halfway between Sydney and Wollongong, was considered to be the 'town most readily adaptable for expansion into a 


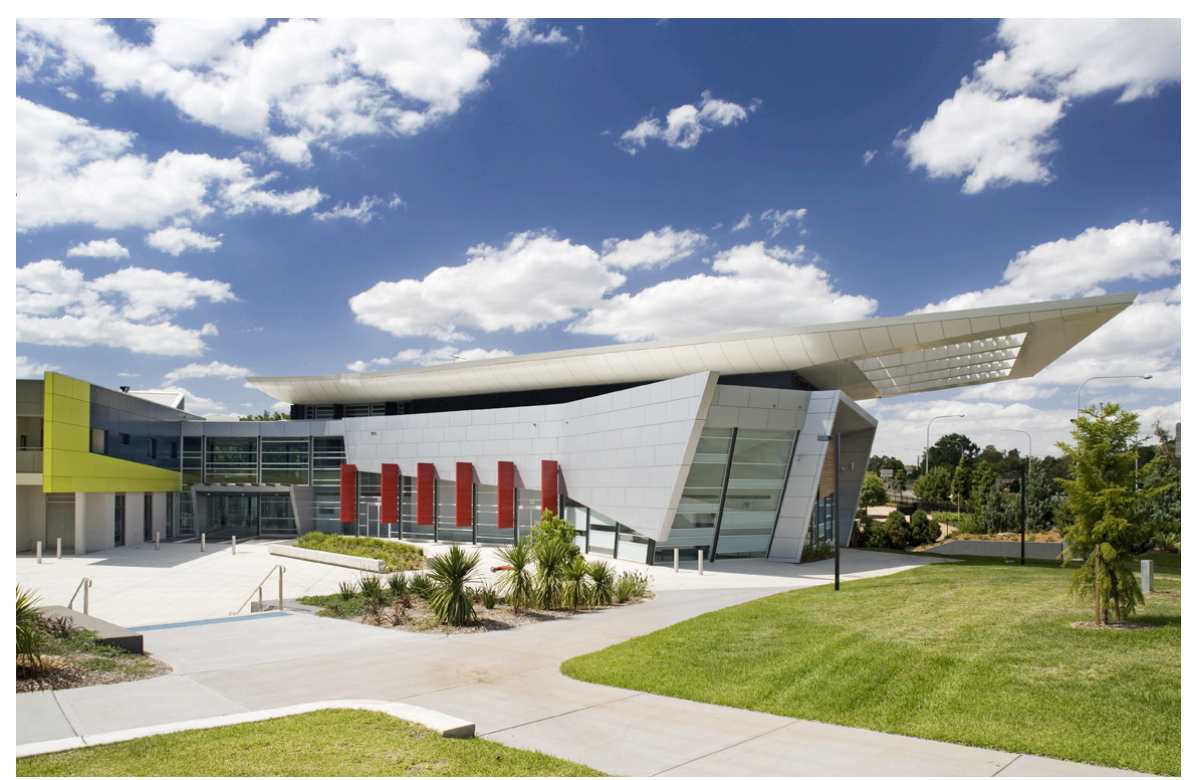

Figure 1 Campbelltown Arts Centre, courtesy Campbelltown City Council

new city' and had a projected population of $30,000 .{ }^{15}$ Intangible cultural attributes such as 'strong individuality', 'civic pride' and 'historical past' were also part of the rationale for Campbelltown's development. ${ }^{16}$ Green belt areas that had been quarantined by the Cumberland Plan were soon released and developed. As a result Campbelltown reached a population in the 1950s that had been projected for the $1970 \mathrm{~s}^{17}$ causing a hastier than planned suburbanisation of the landscape.

While the Cumberland Plan had identified Campbelltown as a satellite city, no additional funds or further planning guidelines had been released and Campbelltown's future remained with the local authority up until the release in 1968 of the Sydney Region Outline Plan 1970-2000AD. ${ }^{18}$ Campbelltown had been growing rapidly from a population of 8840 in 1952 to 25,300 in 1966 - an increase of $285 \% .{ }^{19} \mathrm{New}$ services were required for the community. But the rates income base was insufficient to finance the development of these services. To address the shortage of funds Campbelltown Council took an entrepreneurial approach to raise money for services for these new communities. ${ }^{20}$ The first activity of this type was the inaugural Fisher's Ghost Parade in 1956.

\section{FISHER'S GHOST}

The colonial story of Fisher's Ghost emerged following the murder of local man Fred Fisher in 1826 and the trial of his neighbour George Worrell who was executed for the crime. Paranormal dimensions began to emerge in the story of Fisher's murder as it was recounted through 
poems and published stories in the 1830s. From then on the Fisher's Ghost story proved 'endlessly fascinating' for publishers. ${ }^{21}$ Poems, dramas, novels and journalistic work featured the Fisher's Ghost story throughout the mid to late $1800 \mathrm{~s} .{ }^{22}$ It entered the Australian vernacular in the early 1900s. In 1924, the accused in a civic corruption case was 'looked upon as a fisher's ghost to the officials at the Town-hall... a nightmare' ${ }^{23}$ Earlier, in 1910, the Brisbane Courier used the headline, 'MR. FISHER'S GHOSTS' in reference to Federal Labour Party Leader Mr Fisher's speech to Gympie constituents addressing socialism in relation to Federation. The use of the term 'ghost' implied that Mr Fisher's argument had not represented the true situation. ${ }^{24}$

The silent film era produced the Raymond Longford film Fisher's Ghost that toured across Australia in the 1920s, screening at cinemas with packed audiences. ${ }^{25}$ The film was described as an 'Australian historical drama, based upon a sensational criminal trial in the early days... also made entirely by Australians' ${ }^{26}$ The Longford film was used as evidence in the 1927 Royal Commission into Film that locally produced films could be as popular and commercially profitable as those imported from Hollywood. ${ }^{27}$ In 1925 The Advertiser reported that Fisher's Ghost was 'a world Australian story'. ${ }^{28}$ And in 1932 the Sydney Morning Herald described it as the first really indigenous Australian ghost story. ${ }^{29}$ Two decades later L.A. Triebel, Professor of Modern Languages at the University of Tasmania, wrote that 'no single fact in its history is more responsible for putting Campbelltown "on the map" than the world famous story of Fisher's Ghost' ${ }^{30}$ He indicated that the story had become internationally known and as such functioned as a signifier of place for Campbelltown.

A re-enactment of the Fisher's Ghost story in 1955 drew a large audience of Sydneysiders to Campbelltown. This convinced the local council that the story had enough interest and popular currency to establish an annual Fisher's Ghost Parade. ${ }^{31}$ The Parade was the main event in the inaugural 1956 'Campbelltown Commemorative Festival', which had been organised to 'make the name of Campbelltown and its great potential known throughout the country' and to direct 'financial gains' made from it towards the provision of public services. ${ }^{32}$ Echoes of this municipal sentiment re-emerged in the 2010 debate in which national recognition and profile are considered to be critical outcomes to local cultural policy direction. The Fisher's Ghost float was reported to be the 1956 parade's highlight. ${ }^{33}$ The council float (pictured on page 7) has on its banner: 'Campbelltown Municipal Council Fosters the Growth'. Officially re-named as the 'Festival of Fishers Ghost', the event became 
instrumental in raising funds for the development of public infrastructure including an ambulance station. ${ }^{34}$

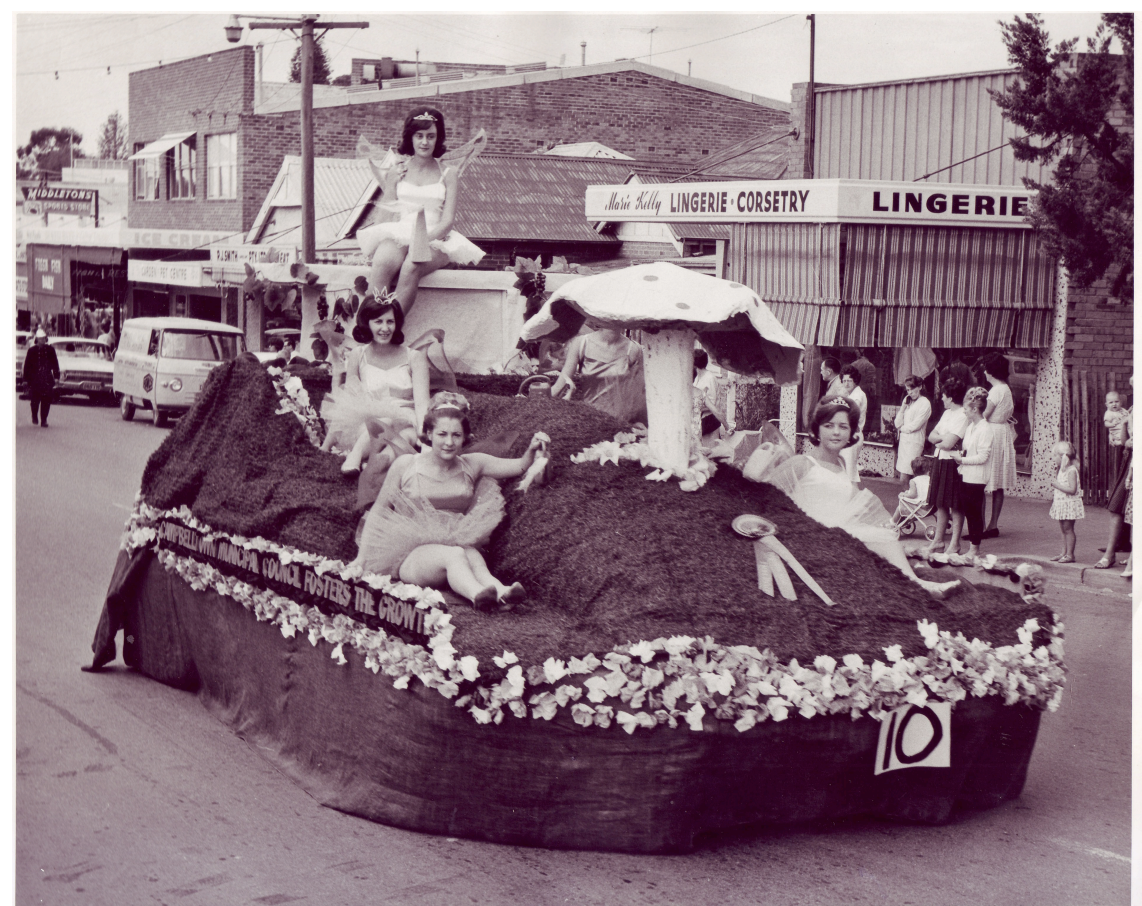

Figure 2 Fisher's Ghost Parade 1956, courtesy Campbelltown City Council

The establishment of the Parade represented a turning point in the trajectory of Fisher's Ghost as a cultural narrative. Where the story had been a subject of fascination to artists, and popular with large audiences, from 1956 local government used this cultural narrative in a deliberate and instrumental way to raise funds for public facilities, forming a foundational direction of cultural policy. While designed to meet a local need, there was also a clear policy intention that sought to build on what Fisher's Ghost had achieved as a cultural narrative in generating recognition for Campbelltown. Now, as an instrument of cultural policy, the story formed the basis for ensuring that Campbelltown would be recognised and valued across Australia as a place that was defined by its modern transitioning environment and its 'great potential'. Carol Liston notes that there was no suburban Campbelltown before $1950 .{ }^{35}$ Once suburbanisation took hold, organised local cultural activity became a vehicle of public policy to support communities through this urban and social transformation.

The venture attracted the attention of The Australia Women's Weekly. It reported that Campbelltown was planning a monument to Fisher's 
Ghost to raise money for an ambulance station. Arguing against a traditional civic style monument, columnist 'Dorothy Drain' advocated for a modern public art work that could become embedded within the increasingly urbanised local environment. 'This', she wrote:

is an age of plastics, and it should be possible to devise some illuminated plastic representation of Fisher... fluorescent lighting, which can do some pretty ghastly things to living complexions, would be ideal... Fisher's Ghost would be a night attraction and would doubtless, in time, be surrounded by snack bars and petrol stations. ${ }^{36}$

Looking back more than a century, the tale of Fisher's Ghost had been told repeatedly through cultural forms to audiences far and wide and as such had emerged both as a Campbelltown specific and national cultural narrative. It functioned to construct an identity for Campbelltown that, while local in its origins, was known to an extent well beyond Campbelltown.

From the 1950s to the late 1960s Australia experienced a period of social change with unprecedented levels of immigration and the rapid growth of cities through outer-metropolitan suburban expansion into places such as Campbelltown. ${ }^{37}$ Modern Australia celebrated 175 years in 1963. There was a growing sense that it needed to develop its own cultural identity as an independent nation state. ${ }^{38}$ This led to a renewed interest in home grown stories from which an Australian identity could be carved rather than one that was transposed from Britain. Bernard Smith has observed that the development of Australian art at the time was underscored by a cultural sense of identity that had grown from local myths and legends. ${ }^{39}$ The legend of Fisher's Ghost had qualified as genuinely Australian and was featured by The Australian Women's Weekly in its coverage of Australia's $175^{\text {th }}$ anniversary celebrations. ${ }^{40}$

Television was to provide a new platform for interpreting and disseminating material relating to the development of an Australian cultural identity. The 1962 Senate Committee Enquiry into the Encouragement of Australian Productions for Television known as the 'Vincent Report' had made recommendations addressing the need to increase Australian content in television programming. ${ }^{41}$ It was thought that the 'field of drama - light, medium, heavy or musical' - offered the most effective form of creating a genuine Australian image ${ }^{42}$ Opera, a dramatic musical form, was ideally suited to the task. And in 1963 the Australian Broadcasting Commission (ABC) produced John Gordon and Robert Allnutt's Fisher's Ghost, the first Australian television opera 
production and, also noted by The Weekly at the time, the first with an Australian historical story. ${ }^{43}$ Gordon and Allnutt's Fisher's Ghost, which was created and produced specifically for the medium of television, was indicative of the $A B C^{\prime}$ 's role in fostering a modern Australian identity.

The $A B C$ 's television opera production continued the trajectory of the Fisher's Ghost cultural narrative and its intersection with cultural policy direction. Regarded as a genuine Australian legend that had been celebrated nationally and beyond in a range of contemporary cultural forms, television brought Campbelltown and its famous story into the cultural consciousness of an ever-expanding suburban Australian nation. The opera shared commonalities with the Longford silent film from nearly forty years earlier in that it had been produced with the most contemporary cultural form of the time - silent film - and was an allAustralian production seen by audiences across the nation. Such contemporary cultural forms and practices offer an effective means to interpret and forge new-generation resonance with past cultural narratives and provide an effective means of renegotiating and inhabiting history. ${ }^{44}$ Originating in colonial times and re-told over decades, the cultural narrative of Fisher's Ghost is conceptually inhabited by the history of Campbelltown. In Campbelltown today, references to Fisher's Ghost, such as its namesake creek and prominent gateway entry signage, show that the narrative, as it is embedded into the physical fabric of the City, continues to be a place-defining feature.

During the 1960s a growing cultural awareness spread into Australia's suburbs and towns as an increasing amount of pictorial work by visual artists was entered into suburban and rural art prize competitions. ${ }^{45}$ This work explored home grown Australian myths and legends and has been described by Bernard Smith as forming a 'prototype for popular art' which had a conceptual and aesthetic accessibility that enabled it to gain an audience with the wider community. Visual arts activity in this sense contributed to engaging suburban communities in the development of a modern Australian cultural identity, which according to Campbelltown history researcher Lynne Marsh provided a broader context for the establishment of an art prize as a new Fisher's Ghost Festival program in $1962 .{ }^{46}$

The Fisher's Ghost Art Prize was established as a program to raise funds for the Festival's general production costs. The establishment of the Art Prize represented a new shift in the application of the Fisher's Ghost story towards cultural policy direction in Campbelltown. It initiated a focus on organised visual arts activity that would sow the seeds of a social movement that was to gain momentum over the following decades 
to influence and become the central focus of the Council's cultural policy direction through to the establishment of the Campbelltown City Bicentennial Art Gallery in 1988. The Gallery was developed by the Council as a result of a social movement that had long campaigned for the provision of a venue to house and support the work of local visual artists. In 2005 the Gallery was re-developed into the Campbelltown Arts Centre. Since then, as the Centre has gained greater recognition and support at a national level, the Fisher's Ghost Art Prize's role has diminished despite it being considered by some in the community to be the highpoint of the local cultural calendar. Still continuing, but lying outside the cultural policy domain which is administered through the Arts Centre, is the festival parade.

\section{CONCLUSION}

The emergence of the Fisher's Ghost story as a cultural narrative and its re-interpretation over many decades put Campbelltown on the map within a broader national cultural consciousness whilst maintaining a keen sense of local interest. In the mid 1950s public officials took an entrepreneurial approach to formalising the narrative as an instrument of policy that could create an identity for Campbelltown as a place of suburban opportunity within a modern Australia that was re-defining itself culturally. Whilst concerned with addressing local community need, this particular instrument of cultural policy was dually concerned with value that could be gained for Campbelltown as a result of nationallevel recognition. Further application of the Fisher's Ghost narrative to support the development of organised visual arts activity through the establishment of an art prize established a linear trajectory of cultural policy direction that has historically underwritten cultural development in Campbelltown into the twenty-first century, as manifested in the Campbelltown Arts Centre.

While the Fisher's Ghost narrative has vastly diminished in its use as a material policy instrument, the fundamental policy binaries that fracture between serving local need and gaining national recognition that underpinned it as a rudimentary policy model remain current. This was clearly seen in the 2010 Campbelltown debate. Despite its omission at a national cultural policy level there are clear indications that suburban Australia is actively engaged in the concerns of cultural policy. An historical approach allows new dimensions to be found that add to the knowledge of how suburban communities and cultural policy concerns intersect. In the case of Campbelltown the discussions and issues raised 
in 2010 do not represent a recent anomaly; they represent a continuation of concerns that had their foundations laid many decades ago.

Penny Stannard has worked in community arts development for over twenty years and in completing a PhD at the University of Technology, Sydney

\section{ENDNOTES}

${ }^{1}$ Gary Makin, 'Letter to editor', Macarthur Chronicle, 20 July 2010, p5.

${ }^{2}$ Mandy Perrin, 'Arts centre must retain relevance for local artists', Macarthur Chronicle, 27 July 2010, p23.

${ }^{3}$ ibid

${ }^{4}$ David Throsby, The economics of cultural policy, Cambridge University Press, Cambridge, New York, 2010, p43.

${ }^{5}$ See Department of Communications and the Arts, Creative Nation: Commonwealth Cultural Policy, Canberra, AGPS, 1994.

${ }^{6}$ Justin O'Connor, 2011, submission to National Cultural Policy Discussion Paper (Online) Available: http: / / culture.arts.gov.au/submissions / justin-oconnorindividual (accessed 18 June 2012); Deborah Stevenson and David Rowe, Submission regarding the National Cultural Policy Discussion Paper, Centre for Cultural Research, University of Western Sydney, 2011, p3; Steven Crittenden, 2012, 'The Getting of Culture', Global Mail, 19 April 2012 (Online) Available:

http: / / www.theglobalmail.org/feature/the-getting-of-culture/200/ (accessed 18 June 2012)

${ }^{7}$ See Richard Florida, The Rise of the Creative Class; And how it's Transforming Work, Leisure, Community and Everyday Life, Basic Books, New York, 2002.

${ }^{8}$ See Chris Gibson and Chris Brennan-Horley, 'Goodbye pram city: Beyond inner/outer zone binaries in creative city research', Urban Policy E Research, vol 24, no 4, 2006, 455-471.

${ }^{9}$ See Emma Felton, Christie Collis and Phillip Graham, 'Making connections: Creative industries networks in outer-suburban locations', Australian Geographer, vol 41, no 1, 2010, pp57-70.

${ }^{10}$ Katya Johanson, 'The Role of Australia's Cultural Council', Doctor of Philosophy thesis, University of Melbourne, 2000, p61.

${ }^{11}$ Jennifer Craik, Re-visioning arts and cultural policy: Current impasses and future directions, ANU EPress, Canberra, 2007, p8.

${ }^{12}$ Deborah Stevenson, 'Cultural Planning in Australia: Texts and Contexts', Journal of Arts Management, Law E Society, vol 35, no 1, 2005, p45. See also Deborah Mills, 'The Necessity of Art', Dialogue, vol 26, no 1, 2007, p36.

${ }^{13}$ Gabrielle Gwyther, 'Once were Westies', Griffith REVEIW, 2008, vol 20, pp81-90.

${ }^{14}$ Carol Liston, Campbelltown: The Bicentennial History, Allen \& Unwin, Sydney, 1988, p197.

${ }^{15}$ Cumberland County Council, Campbelltown, a new city in the County of Cumberland, 1960, p9.

${ }^{16}$ William Bayley, History of Campbelltown, New South Wales, Campbelltown Municipal Council, 1974, p175.

${ }^{17}$ Liston, op cit, p212.

${ }^{18}$ Dennis Winston, Sydney's Great Experiment: The Progress of the Cumberland County Plan, Angus and Robertson, Sydney, 1957, p81.

${ }^{19}$ See Australian Bureau of Statistics, 1954, Year Book Australia, Canberra, p333; Australian Bureau of Statistics, 1966, Year Book Australia, Canberra, p196.

${ }^{20}$ Liston, op cit, p211.

${ }^{21}$ Liston, op cit, pp66-67.

${ }^{22}$ Liston, op cit, pp64-66. Mid nineteenth century published works that were inspired by or referred to the Fred Fisher story included 'The Sprit of the Creek', 1832, 
(anonymous) published in Hill's Life in New South Wales; 'Fisher's ghost: A Legend of Campbelltown' (anonymous), published in Tegg's Monthly Magazine, March 1836; R.M. Martin (1836) History of the British Colonies; Charles Dickens (1855) Household Words which included a version of the story by John Lang; L'Ami de la Maison (1856) also included the Lang version; Marcus Clarke (1875) For the term of his natural life; WH Rusden (1883) History of Australia; WH Suttor (1887) Australasian Stories Re-told.

${ }^{23}$ The Mercury, Friday 14 November 1924, p2.

${ }^{24}$ The Brisbane Courier, Friday 25 February 1910, p4.

${ }^{25}$ Screenings of the film were reported in local papers as follows: The Mercury, Tuesday 10 February 1925, p2; Sunday Times, Sunday 14 March 1926, p3; Morning Bulletin, Monday 28 September 1925, p5; Advocate, Wednesday 20 July 1927, p5; Brisbane Courier, Wednesday 17 December 1924, p23.

${ }^{26}$ Brisbane Courier, Saturday 18 August 1928, p6.

${ }^{27}$ Amid growing concern over increased foreign dominance of the Australian film industry, a Commonwealth Royal Commission heard 250 submissions from local film representatives and members of the public. Its recommendations, released in March 1928, included the implementation of a quota for features produced in Australia and other Empire countries. Aimed at providing a guaranteed level of exhibition for Australian films, the quota legislation was never passed. See A. Pike and R. Cooper, Australian Film 1900-1977, Oxford University Press, Melbourne, 1998, p 87. In 1925 The Hobart Mercury reported 'When "Fisher's Ghost" was first placed on the market here it was subjected to a boycott by foreign agents, and it was refused by many picture-theatre managers. But it proved to be one of the best Australian successes yet produced', The Hobart Mercury, Tuesday 13 January 1925, p2. In advocating for the popularity that Australian films have with local audiences, evidence given to the Commission by a Mr J. George, 'who is engaged in picture production' referred to an acquaintance of his who in screening Fisher's Ghost took only $£ 1$ less than the box office record set by his screening of The Ten Commandments. See The West Australian, Wednesday 19 October 1927, p16.

${ }^{28}$ The Advertiser, 21 April 1925, p7.

${ }^{29}$ The Sydney Morning Herald, 25 January 1932, p10.

${ }^{30}$ L.A. Triebel, Fisher's Ghost and other essays, F. W. Cheshire, Melbourne, 1950, p5.

${ }^{31}$ Liston, op cit, p211.

${ }^{32}$ Campbelltown-Ingleburn News, 23 October 1956, p1.

${ }^{33}$ ibid, p11.

${ }^{34}$ ibid, p1.

${ }^{35}$ Liston, op cit, p212.

${ }^{36}$ The Australian Women's Weekly, Wednesday 15 April 1956, p20.

${ }^{37}$ Katya Johanson, The Role of Australia's Cultural Council, Doctor of Philosophy, University of Melbourne, 2000, p61.

${ }^{38}$ Johanson, op cit, p61.

${ }^{39}$ Bernard Smith, Australian painting 1788-1990, Oxford University Press, Melbourne, 1991, p348.

${ }^{40}$ The Australian Women's Weekly, 25 September 1963, p170.

${ }^{41}$ Johanson, op cit, p83.

${ }^{42}$ Senator Hanna, Commonwealth Debates, Senate 18 March 1964, p369 in Johanson, op cit, p84.

${ }^{43}$ Australian Broadcasting Corporation, 2011, 'ABC TV Firsts', 50 Years of ABC $T V,($ Online) Available: http: / / www.abc.net.au / tv / 50years / didyouknow / firsts.htm (Accessed 20 May 2012). See also The Australian Women's Weekly, Wednesday 25 September 1963, p17.

${ }^{44} 200$ Gertrude Street submission cited in Contemporary Visual Arts and Crafts Inquiry, the 'Myer Report', Commonwealth of Australia 2002, Canberra, p47.

${ }^{45}$ Bernard Smith, Australian painting 1788-1990, Oxford University Press, Melbourne, 1991, p350. 
${ }^{46}$ Lynne Marsh, 'The History of the Fisher's Ghost Art Award' submitted through BA Hons program Historiography and Research Methods in History, (institution unknown), 1995, p10. Held in Campbelltown City Council Local Studies Collection. 